\title{
EXTENT OF DAMAGE TO COCONUT PALMS CAUSED BY SUPER CYCLONE IN ORISSA AND PATTERN OF THEIR RECOVERY
}

By

\author{
D.K. Dash', D.P. Ray ${ }^{2}$ and H. Hameed Khan ${ }^{3}$
}

\begin{abstract}
During the Super cyclone (October, 1999) in the coastal districts of Orissa, 26,836 hectares of coconut garden having 46,96,300 palms were severely affected. A survey of affected palms in the selected villages classified the palms as (i) uprooted (11.3 percent) (ii) palms with complete crown damage (23.3 percent) (iii) palms with severe damage to the crown (32 percent) and (iv) palms with partial crown damage (34 percent). The affected palms lost most of their valuable leaves and spadices in their varying stages of development. The recovery of palms started after 2 months of damage in the form of production of new leaves. The spadices production started after 4-5 months of damage. The number of palms entered the fresh reproductive stage is of low percent, which may lead to in 2-3 years delay in nut production by the palm. Regular manuring with organics and inorganics, adequate plant protection are suggested to rejuvenate the palms.
\end{abstract}

\footnotetext{
${ }^{1}$ Asst.Professor Horticulture (Breeding), AICRP on Palms, OUAT, Bhubaneswar

${ }^{2}$ Professor and Head, Department of Horticulture, OUAT, Bhubaneswar.

${ }^{3}$ Project Co-ordinator (Palms), CPCRI, Kasaragod, Kerala
} 


\section{INTRODUCTION}

Coconut is one of the important perennial horticultural crops grown in all the coastal districts of Orissa. The area and production of coconut is 54.5 thousand hectare producing 7951 million nuts respectively (1998-1999). During October, 1999 a super cyclone hit the coastal districts of Orissa with heavy rain and a wind velocity more than $250 \mathrm{kms}$ per hour and devastated many perennial horticultural crops. It caused a heavy loss to the coconut growers of the state severely damaging 26,836 hectares of coconut gardens in the coastal area growing approximately 46,96,300 palms (source: Directorate of Horticulture, Orissa, 2000).

The observation on affected palms were taken from November 1999, till October-2000 under this study to assess the nature and intensity of damage caused to coconut palms by super cyclone and their mode of recovery of palms from different degree of damages. The observation was recorded from November 1999, till October-2000.

\section{METHODOLOGY}

The nature and extent of damage caused to coconut Palm by cyclone was assessed and recorded at Kakatpur block of Puri district. In this block around 1,21,389 coconut palms have been affected with different degrees of damage. In the three villages (Raish, Bajapur, Bangurigaon) of Kakatpur block of Puri district the numbers of palms affected during cyclone were 2155, 2564 and 1900 respectively in Raish, Bajapur, and Bangurigaon. 
For grouping or categorizing the affected palms based on degree of damage (Thampan, 1993), the whorl of crown was taken into consideration. Based on degree of damage the affected palms were grouped into four categories (i) Uprooted palms denoted as $1 \mathrm{st}$ category (ii) Complete crown damage denoted as 2nd category,(iii) Severe crown damage denoted as 3rd category, (iv) partial degree of damage to the crown denoted as 4 th category. The percentage of damage in particular village was computed on leaf, spadix, bunch and nut in the affected palms (Table-1).

For taking these observations, twenty palms of each category were selected randomly from each of the village. The percent of palms that produced new leaves were observed whenever the leaf emergence occurred in a particular month in all the categories. The number of spadices produced before cyclone was recorded by counting the damaged inflorescence (completely broken/ inflorescence with or without button or nuts/the presence of inflorescence stalk etc.). The observation were taken at monthly intervals from the date of cyclone - i.e. from November, 1999, till October -2000 .

The palms selected for the study are of the variety Sakhigopal Tall of 40 to 50 years of age traditionally planted at closer spacing of 10 and 15 feet between palms. The farmers of the selected villages do not resort to any fertilizers application or irrigation, but the crowns of the palms were cleaned once in a year. 


\section{RESULTS AND DISCUSSION}

The details of damage caused by cyclone are given in the Table- 2 for the three-selected villages. The 1 st category of damage accounted only for 11.3 percent, compared to the incidence of other three categories of damage. This may be due to the closer spacing of palms, which surprisingly offered more resistance to the wind. It was also noticed that $3 \mathrm{rd}$ and $4^{\text {th }}$ category of damage was on higher side as compared to 2 nd category.

Maximum numbers of broken leaves (22.3) were recorded under 2 nd category of damage. (Table-3). In most of the palms under this category, leaves were found to be blown out of the crown from middle whorl, leaving 4.7 numbers of leaves on lower whorl with 2.46 number of bunches having 12 matured nuts when an average for 20 palms was computed. Under this category cabbage of most palms have been damaged are bud rot and red palm weevil incidence was also noticed. Breaking and twisting of leaves (17.5 Nos.) was recorded in the second and third whorl, in 3rd category of damage. Under this category sword leaf along with the bundle of young leaves of whorl was found to be broken at petiole portion. Around 9.5 numbers of leaves were recorded in the lower, middle and top whorl with 3.1 number of bunches having 11 nuts at successive stage of development. Partial damage to the cabbage could not be assessed as most of the leaves in the $3 \mathrm{rd}$ and 4 th set of whorls had been damaged. Under 4th category degree of damage 14.5 Nos. of broken and twisted leaves and were observed. The severity of damage was recorded in all the three whorls of crown towards windward side while most of the leaves were twisted in leeward side. Palms with 12.5 nos. of leaves on the crown having 3.76 nos. inflorescence and a 
total of 18 nuts at varying stages of development were recorded, after the cyclone.

Irrespective of categories of damage the affected palms have lost more than 80 percent inflorescence bearing nuts at various stages of development affecting future yield of palms. The inflorescence were either broken or the buttons blown out. This loss to palms will result in low or no nut yield in coming two years.

Observations were also recorded on the spadices or inflorescence and bunch which had escaped the cyclone (Table-4). It was noticed that after cyclone button or nut drop was 61.0, 39.0 and 49.9 percent under 4 th, 3rd and 2 nd category of damage respectively. This may be due to cyclone shock to palms resulting in damage to the root system and short supply of nutrients, because due to the whirling wind and twisting of leaves and spadices. Good nuts were harvested form the $2^{\text {nd }}$ category damaged palms, where matured nuts were left intact after cyclone. Empty nuts of 27.7 and 33 percent were also recorded from 3rd and 4th category of palms, respectively.

In general it was observed that emergence of leaf and spadices production ceased for a short while after cyclone damage to the palms. The leaf emergence was observed after 2 months whereas spadix production was observed only after 5 to 6 months. This may be due to damage to the leaf prim odium in the cabbage or bud.

It was observed that in the of 3rd and 4th category 21.6 and 24.9 percent of palms have put forth leaves after two months of damage (Table-5). Maximum percent of palms have produced new leaves after three months of damage; whereas palms under complete crown damage the leaf production (2nd category) damage was poor with only 2.5 percent palms producing small and stunted leaves ( 2 
number) during the one year of observation. The 3rd and 4th category of palms recorded 5 and 8 numbers of leaves respectively during one year of growth after cyclone. During the observation it was noticed that 97.4 and 100 percent affected palms under 3rd and 4th category respectively produced new leaves. Nevertheless, that 33 and 3.6 percent of palms 2 nd and 3rd category of damage have died due to infection of bud.

In general the production of spadices by the cyclone-affected palms (Table-6), were very poor. The 1 st category of palms did not put forth any spadices till the end of October 2000. Under the 2nd category, $7.5 \%, 9.5 \%$ and 11.5 percent of palms produced spadix at different months, totaling to 28.5 percent of palms with an average of 3.4 number of spadices having 5.4 number of female flowers. The 3rd category palms entered into new re-productive phase from 3 rd month onwards and recorded 5.5, 9.6, 11.3 and 12.4 percent palms producing spadix. Under this category 38.8 percent of palms produced spadix in one year with an average 5 spadices with 7 buttons each. It was also observed that, in some cases there was no spadix production even at the $11^{\text {th }}$ and $12^{\text {th }}$ months of damage due to cyclone. This may be due to failure of spadix development or its abortion during the development period. Because in coconut the primordium of the spike let of inflorescence is formed about 15 months before opening of spathe (Menon and Pandalai, 1988), the cyclone shock might have caused drying or damage to the growing point, resulting in the abortion of inflorescence and female flowers. In few cases the palms, produced panicles only with male flowers initially and however but in the subsequent months the panicles also had female flowers. As the palms lost most of its leaves the inadequate supply of photosynthates to developing inflorescence may 
also cause abortion of female flowers. Though the affected palms entered into a new re-productive stage producing inflorescence, the majority of the affected palms (60 to 70 percent) are yet to produce spadices.

\section{CONCLUSION}

In the different categories of affected palms, the palms with complete crown damage did not recover well and hence have to be removed and new seedlings are to be planted. The palms with severely damaged crown and partially damaged crown are photosynthetically inefficient and nutritionally poor due to loss of valuable leaf biomass. Integrated nutrient management coupled with regular agronomic practices and proper pest and disease management can rejuvenate these palms. Though the affected palms slowly recovered, delay in spadix production and with few female flowers will be further delaying the regular yield. The palms affected by cyclone may attain its original yielding capacity after only 2 to 3 years and with proper management practices will perform better.

\section{ACKNOWLEDGEMENT}

The authors express their sincere gratitude to - Mr. C. Sahoo, A.H.O, Konark, Mr. Shyam Lal, C.D.B. Bhubaneswar and Directorate of Horticulture, Orissa for assistance in getting valuable information on cyclone damage and help rendered for taking observations. 


\section{REFERENCES}

Menon, K.P.V. and Pandalai, K.M. (1958) The Coconut Palm - A Monograph

Thampan, P.K. (1993), Hand Book of Coconut Palm. Oxford \& I B H Publish Co. Pvt. Ltd. 
Table -1. Type of Damage and Nature of Crown Damage caused by the Super cyclone in the Coastal Districts of Orissa

\begin{tabular}{|c|c|l|}
\hline Type of Damage & Category & \multicolumn{1}{|c|}{ Nature of Damage } \\
\hline 1. Uprooting & 1 st & $\begin{array}{l}\text { Uprooting of palm from ground level } \\
\text { or breaking of the stem portion }\end{array}$ \\
\hline $\begin{array}{c}\text { 2. Complete Crown } \\
\text { Damage }\end{array}$ & 2nd & $\begin{array}{l}\text { Few leaves of lower (1st.) whorl, } \\
\text { major leaves of middle (2nd) and top } \\
\text { (3rd) whorl are completely broken } \\
\text { giving appearance of a beheaded } \\
\text { palm. The bud (4th) is damaged or } \\
\text { affected. 80-90\% spadices damaged } \\
\text { or blown out. }\end{array}$ \\
\hline $\begin{array}{l}\text { 3. Severe Crown } \\
\text { Damage }\end{array}$ & 3rd & $\begin{array}{l}\text { Majority of leaves of middle whorl } \\
\text { are damaged. The young leaves of } \\
\text { top whorl are broken, twisted or } \\
\text { removed. The spadices with varying } \\
\text { stages of nut are damaged (85\%). } \\
\text { Palms give an appearance of crown } \\
\text { twisting. }\end{array}$ \\
\hline 4. Partial Crown & 4th & $\begin{array}{l}\text { The major leaf and spadices affected } \\
\text { in the windward by breaking or } \\
\text { removal. The leaf and spadices of } \\
\text { leeward side are twisted and broken. } \\
\text { The top young leaves were broken. } \\
80-85 \% \text { of spadices were damaged. }\end{array}$ \\
\hline
\end{tabular}


Table.2.Number of palms damaged during the cyclone in the affected villages and percent of palms under different category of damage

\begin{tabular}{|l|l|c|c|c|c|c|}
\hline $\begin{array}{l}\text { SI. } \\
\text { No. }\end{array}$ & $\begin{array}{c}\text { Name of the } \\
\text { affected village }\end{array}$ & $\begin{array}{c}\text { Nos. of } \\
\text { Palm } \\
\text { damaged }\end{array}$ & \multicolumn{4}{|c|}{$\begin{array}{c}\text { Percent of palms under different } \\
\text { Category of damage }\end{array}$} \\
\hline 1. & Raish (249) & 2155 & 14 & 24 & 26 & 28 \\
\hline 2. & Bajapur (414) & 2564 & 9 & 18 & 32 & 41 \\
\hline 3. & Bangurigaon(147) & 1900 & 11 & 28 & 38 & 23 \\
\hline & Total & 6619 & $11.3 \%$ & $23.3 \%$ & $32 \%$ & $34 \%$ \\
\hline
\end{tabular}

Figures in the parenthesis denote numbering of families in the village.

Table 3. Number of leaves damaged in affected palms under different category of damage

\begin{tabular}{|c|c|c|l|}
\hline $\begin{array}{c}\text { Categor } \\
\mathbf{y}\end{array}$ & $\begin{array}{c}\text { Average number } \\
\text { of } \\
\text { leaves damaged/ } \\
\text { lost }\end{array}$ & $\begin{array}{c}\text { Number of leaf } \\
\text { found on the } \\
\text { crown }\end{array}$ & \multicolumn{1}{|c|}{ Remark } \\
\hline 2nd & 22.3 & 4.7 & $\begin{array}{l}\text { Most of the leaves from } \\
\text { the top three set of } \\
\text { whorl lost. }\end{array}$ \\
\hline 3 rd & 17.5 & 9.5 & $\begin{array}{l}\text { Most of the leaves in } \\
\text { middle and top whorl } \\
\text { were lost or damaged }\end{array}$ \\
\hline 4 th & 14.5 & 12.5 & $\begin{array}{l}\text { Leaves of lower and } \\
\text { middle whorl were } \\
\text { found damaged }\end{array}$ \\
\hline
\end{tabular}


Table 4. Nature of damage to the spadices or bunch in the different category of damage

\begin{tabular}{|c|c|c|l|l|l|l|}
\hline $\begin{array}{l}\text { Sl. } \\
\text { No. }\end{array}$ & $\begin{array}{c}\text { Categor } \\
\text { y of } \\
\text { damage }\end{array}$ & $\begin{array}{l}\text { Number of } \\
\text { spadices } \\
\text { present on } \\
\text { the Palm } \\
\text { (before } \\
\text { cyclone) }\end{array}$ & $\begin{array}{l}\text { Number } \\
\text { of } \\
\text { spadices } \\
\text { retained } \\
\text { (after } \\
\text { cyclone) }\end{array}$ & $\begin{array}{l}\text { Average } \\
\text { number } \\
\text { of nut in } \\
\text { bunches }\end{array}$ & $\begin{array}{l}\text { Percent } \\
\text { of nut } \\
\text { droppe } \\
\text { d }\end{array}$ & $\begin{array}{l}\text { Percent } \\
\text { of empty } \\
\text { nut }\end{array}$ \\
\hline 1. & 2nd & N.A. & 2.46 & 12 & 49.9 & - \\
\hline 2. & 3 rd & 23.5 & 3.06 & 11 & 39.0 & 27.7 \\
\hline 3. & 4 th & 24.0 & 3.7 & 18 & 61.0 & 33 \\
\hline
\end{tabular}

Table 5. Percent of affected palms produced leaves and number of leaves produced after cyclone damage

\begin{tabular}{|c|c|c|c|c|c|c|c|}
\hline \multirow{2}{*}{ Sl. No. } & \multirow{2}{*}{$\begin{array}{l}\text { Categor } \\
\mathbf{y}\end{array}$} & \multicolumn{3}{|c|}{$\begin{array}{c}\text { Percent of Palm } \\
\text { produced leaves after } \\
\text { (months) }\end{array}$} & \multirow{2}{*}{$\begin{array}{l}\text { Total of } \\
\text { palms } \\
(\%)\end{array}$} & \multirow{2}{*}{$\begin{array}{l}\text { Damaged } \\
\text { Palm that } \\
\text { died }\end{array}$} & \multirow{2}{*}{$\begin{array}{l}\text { Numbe } \\
\text { r of leaf } \\
\text { in a } \\
\text { year }\end{array}$} \\
\hline & & 2 & 3-4 & 5-6 & & & \\
\hline 1. & 2nd & - & - & 2.5 & 2.5 & 33 & 2 \\
\hline 2. & $3 \mathrm{rd}$ & 21.6 & 63.3 & 12.5 & 97.4 & 3.6 & 5 \\
\hline 3. & 4 th & 24.9 & 75.1 & - & 100 & - & 8 \\
\hline
\end{tabular}


Table 6. Percent of affected Palm's produced spadix and number of spadices produced after cyclone

\begin{tabular}{|c|c|c|c|c|c|c|c|c|}
\hline \multirow{2}{*}{$\begin{array}{l}\text { Sl } \\
\text { No. }\end{array}$} & \multirow{2}{*}{$\begin{array}{l}\text { Categor } \\
\mathbf{y}\end{array}$} & \multicolumn{4}{|c|}{$\begin{array}{l}\text { Percent of palm that } \\
\text { produced spadix month } \\
\text { after damage }\end{array}$} & \multirow{2}{*}{$\begin{array}{c}\text { Total } \\
\text { No, of } \\
\text { Palm } \\
\text { (percent) }\end{array}$} & \multirow{2}{*}{$\begin{array}{l}\text { Avg. } \\
\text { nos. of } \\
\text { spadix } \\
\text { per } \\
\text { year }\end{array}$} & \multirow{2}{*}{$\begin{array}{c}\text { Average } \\
\text { buttons } \\
\text { produce } \\
\quad \text { d } \\
\text { (number } \\
\text { ) }\end{array}$} \\
\hline & & $3-4$ & $5-6$ & $7-8$ & $9-10$ & & & \\
\hline 1. & $2 \mathrm{nd}$ & - & - & - & - & - & - & - \\
\hline 2. & $3 \mathrm{rd}$ & - & 7.5 & 9.5 & 11.5 & 28.5 & 3.4 & 5.4 \\
\hline 3. & 4th & 5 & 9.6 & 11.3 & 12.4 & 38.8 & 5.0 & 7.0 \\
\hline
\end{tabular}

